\title{
Oil as a Lubricant in the Ancient Middle East
}

\author{
Michael Nosonovsky \\ National Institute of Standards and Technology \\ 100 Bureau Dr., Stop 8520, Gaithersburg, MD 20899, USA \\ Michael.Nosonovsky@nist.gov
}

( Manuscript received 12 January 2007; accepted 8 March 2007; published 15 April 2007 )

\begin{abstract}
There is a significant interest toward the history of tribology in both engineering and historical communities. However, there is a gap between engineers and historians in their approach to the topic, and existing literature sometimes overlooks various cultural influences, in particular, oriental ones, which affected the tribological science and technology. We consider the early history of lubrication and show that while the evidences of usage of lubricants (water, gypsum, and animal fats) in Ancient Egypt in $2^{\text {nd }}-3^{\text {rd }}$ millennia BC are hypothetic, rather than established facts, the Hebrew Bible contains earliest records of using oil as a lubricant. In particular, the account of rubbing the shield of King Saul $\left(11^{\text {th }}\right.$ century BC) is discussed as well as other similar cases. These findings allow us to better understand the universal nature of history of science and technology as a multicultural phenomenon.
\end{abstract}

Keywords: history of lubrication, olive oil, gypsum, ancient Middle East

\section{Introduction}

Although the words "tribophisics/tribology" were coined only some 60 years ago by D. Tabor and H.P. Jost from the Greek word tribos, meaning "rubbing", tribological knowledge and technology existed from the earliest time ${ }^{1)}$. The first studies on the history of friction, lubrication, and wear were published in the second third of the $20^{\text {th }}$ century in the US, Soviet Union and Europe by leading engineers and scientists. Parish ${ }^{2)}$ published, probably, the first review of the history of lubrication in the magazine Mill and Factory. The monograph by Kragelsky and Shchedrov ${ }^{3)}$ was published by the Soviet Academy of Science and concentrated upon the history of physical, mechanical and mathematical approaches toward friction since the pioneering works of Leonardo da Vinci. When the journal Wear was launched in 1957, articles by C. Davison on wear prevention in early history appeared there ${ }^{4)}$. In addition to these early studies, a number of new publications have emerged in the past 20 years, including the monographs by Bartz and Dowson ${ }^{1,5,6)}$. Short historical introductions, which survey the development of tribology form the ancient time, are often included into tribology textbooks. Tribology journals publish articles on the history of tribology, and sections on the history and archaeology of tribology are organized at many specialized conferences. The new term "archeotribology" was suggested for the investigation of tribological properties of archaeological artefact, including coatings, sledge surfaces etc. and investigation of ancient technology used to create them $^{7,8)}$

Because of this interest toward the history of the tribology both in the engineering and historical scientific communities, a number of publications have appeared in the past years, reporting and reviewing research results in this field ${ }^{9)}$. The existing literature has concentrated upon the development of tribology in Europe, from the Greek and Roman times through the European Middle Ages toward the European Renaissance (and in particular, the works of Leonardo da Vinci) and the Industrial Revolution. However, it overlooks to a large extent many other cultural influences, such as oriental.

It has been discovered recently, that the history of the European Renaissance is far more complex and multicultural, than it was earlier believed, and that various non-European influences played an important role in development of the pre-modern science and technology. Thus, possible contribution of Arab, Persian, Ottoman, and Jewish astronomers into the development of the Copernicus system led to a discussion on the matter ${ }^{10)}$, which provided with new insights on the nature of the European Renaissance ${ }^{11)}$. In our opinion, it is worthwhile to look with more attention at the tribological knowledge of oriental cultures, in particular, at the tribological information in the historical books of the Hebrew Bible (HB, alternatively called the Old Testament, $13^{\text {th }}-3^{\text {rd }}$ centuries BC). 
In the present work we investigate tribological data, which may be found in the HB by considering direct references and by analyzing semantics of the Biblical Hebrew lexicon related to tribology. We show that evidences of using the oil lubricants for softening surfaces and making them slippery are found already in biblical texts. While scholars attributed the first systematic study of lubricants to the Roman author Pliny the Elder (c. 23-19 AD) ${ }^{1}$, we show that the first recorded use of oil as a lubricant is found in the story about the shield of Judean king Saul ( $11^{\text {th }}$ century BC). This finding helps us to better understand the universal nature of history of science and technology as a multicultural process.

\section{Earliest history of lubricants}

It is generally believed that lubricating materials were introduced in Egypt during the early civilizations period $^{1,2,5)}$. According to Dowson ${ }^{1)}$, among the earliest evidences of using lubricants are: (1) hydrated calcium sulphate (gypsum) was used to form the thin bed of viscid mortar to slide huge stone blocks for building of pyramids in the third millennium BC, (2) water lubrication was used for transportation of heavy stone blocks, as shown in paintings from Saqqara (circa 2400 $\mathrm{BC}$ ) and El-Bersheh (c. $1880 \mathrm{BC}$ ), (3) a chariot from about 1400 BC from Egypt with traces of a lubricant (presumably, mutton or beef tallow) at its axle.

The first evidence is gypsum used to form the thin bed of viscid mortar to slide huge stone blocks for building of pyramids in the third millennium BC. Following Clarke and Engelbach ${ }^{12)}$, Dowson writes that the role of mortar in the megalithic building was different from that today. For huge stone blocks, the cohesive power of mortar is of little importance, because of high friction between the blocks; however, it could serve as a sort of lubricant, decreasing friction and thus allowing to position finely the blocks at a desired location with high accuracy ${ }^{1)}$. This technique is not really lubrication per se, but rather a method to fit the huge stones together.

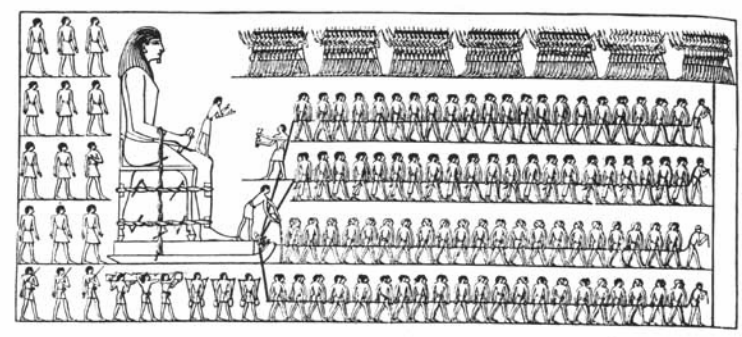

Fig. 1 Painting from El-Bersheh, circa 1880 BC, showing transportation of a giant statue. Man in front of the statue pouring liquid from a jar. Some historians suggested that the liquid served ceremonial purposes, whereas some engineers suggested that this is one of the first recorded cases of lubrication. The figure entered many tribology textbooks.
The second evidence is the water lubrication allegedly used for transportation of heavy stone blocks, as shown in paintings from Saqqara and El-Bersheh, and it is even more questionable than the first one. The painting from the tomb of the Great Chief of the Hare Nome Tehuti-Hetep (or Djehutyhotep) in El-Bersheh (circa 1880 BC) shows transportation of a huge statue by many men (Fig. 1). D. Dowson (1998) writes:

"A most interesting feature of this painting is that it shows an officer standing in front of the pedestal pouring lubricant from a jar on to the ground immediately in front of the sledge. Sir A. H. Layard ${ }^{13)}$ states that the lubricant was probably grease, but the scant archaeological evidence offers little support to this view, and others have described the lubricant as water... I am inclined to agree with the view that water was used as the lubricant, since the firmest evidence comes from the translation of the inscriptions on the wall pictures from El-Bersheh. Newberry recorded the following inscription related to the three men with yokes and jars: "carrying water by [men of] the house of eternity".

Newberry also wrote '... Another figure standing on the base pours water from jar in front of the sledge, perhaps only the ceremonial act, since even in large quantities water poured upon the ground could not assist the dragging...,"1).

Interestingly, W.F. Parish, who was an engineer and not a historian, assumed that the liquid jar shown in the El-Bersheh painting contained "dark-green oil", while the "extra men are shown with shoulder yokes suspending other vases with the days supply of oil"2). This contradicts the historical data that olive oil was practically unknown in Egypt during that period ${ }^{14)}$, and Dowson does not consider this possibility plausible. Then he argues, that "the sledge was drawn over wooden planks lubricated by water", and that the man pouring water is "the first recorded oiler, greaser, lubrication engineer or tribologist"1). Later he refers to an even earlier painting from Saqqara (c. 2400 BC) of transporting the stature of $\mathrm{Ti}$, which has a similar motif of a man pouring liquid form jar in front of the sledge, as an image of "the earliest recorded tribologist"1).

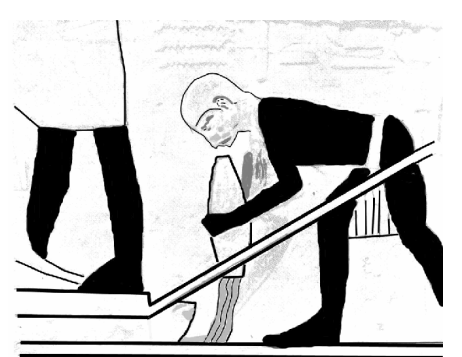

Fig. 2 A man pouring water, presumably as a lubricant, in front of a sledge with a statue of Ti in Saccara (Egypt), circa $2400 \mathrm{BC}$.

In an attempt to further support his claim, Dowson (1998) makes a remarkable calculation. According to 
him, the painting from El-Bersheh shows 172 men who, assuming average force of a slave as $800 \mathrm{~N}$, could achieve total drag force of $172 \times 800 \mathrm{~N}=137.6 \mathrm{kN}$. Assuming (quite arbitrary) the weight of the colossus $600 \mathrm{kN}$, he then calculates the coefficient of friction as $\mu=60 / 137.6=0.23$ and compares it with that of wet wood-on-wood $(\mu=0.2)$, concluding that "the sledge was indeed sliding over lubricated planks of wood" 1 ).

Of course, it is a bit naïve to assume that the painting shows the exact number of workers dragging the statue. For comparison, the painting from Saqqara shows much smaller number of workers (in fact, only three men are shown, which would result in an unrealistically small value of $\mu$ even if modern lubricants were used). Furthermore, it should be kept in mind that tomb paintings and inscriptions are usually sacral in their motifs, and pouring liquid had a ritual or ceremonial meaning in many cultures, so the words "carrying water by the house of eternity" can hardly be interpreted as a direct reference for water lubrication. Moreover, there is another man shown in the same painting, holding a censer and fanning the burning incense in honor of the statue, which of course is another ceremonial act ${ }^{15)}$. While Newberry and other Egyptologists tend to consider the El-Bersheh motif as a ceremonial act, engineers enthusiastically claimed that it depicts lubrication $^{1,2)}$.

The third evidence is the Egyptian chariot from about $1400 \mathrm{BC}$ with presumed traces of the lubricant was found in early $20^{\text {th }}$ century during excavations in a tomb. The sample, which was analyzed by the museum of Cairo in the 1920s, was small. D. Dowson, writes, again following W.F. Parish:

"The sample was small, weighting about $0.001 \mathrm{oz}$ $(0.038 \mathrm{~g})$, sticky and slightly greasy. It contained road dirt such as quartz sand, compounds of aluminium, iron, and lime. It had a melting point of $49.5^{\circ} \mathrm{C}\left(121.1^{\circ} \mathrm{F}\right)$, which suggested that it had been mutton or beef tallow, either of which would have proved suitable for axle lubrication in such a warm country"1).

As we see, the evidence is also a bit shaky, since only a microscopic sample of the presumed lubricant was found (weighting less than $0.04 \mathrm{~g}$ ), and it was mostly the "road dirt", whereas the conclusion of the laboratory of the Cairo Museum, that it was an animal fat ("mutton or beef tallow") was based upon the value of the melting temperature, rather than upon a chemical analysis. Furthermore, Egypt is certainly a "warm country", however, even in the summer season, temperatures in most parts of Egypt are certainly below $49.5^{\circ} \mathrm{C}$, above which the lubricant was presumably intended to operate.

Although it is expected, that some lubricants were used for chariot wheels, the actual evidence does not seem to be strong. Chronologically, next reference for the lubricants given by Dowson is in China of the period of the Warring States (c. $4^{\text {th }}$ century BC), where lubricants were presumably used for wheels of chariots, however, the nature of the lubricant is not discussed and its presence is speculative ${ }^{1)}$.

Finally, the list of lubricants was presented by the Roman author Pliny the Elder (c. AD 23-79) and this is the first solid evidence of the use of lubricants ${ }^{1)}$. The further development of tribology is associated in the literature geographically with Europe.

We can conclude that the earliest history of lubricants is not that well established. Although suggestions have been made that animal fat, gypsum and water were used for lubrication, these are hypotheses, rather than proven facts. The real history of lubricants starts with the introduction of oil, which was extremely rare in both Egypt and Mesopotamia and originated from the eastern part of the Mediterranean ${ }^{14,16,17)}$. In the absence of direct evidence, we will concentrate first upon linguistic data of the Biblical Hebrew regarding oil, lubrication, slipping and rubbing and semantics of the corresponding lexicon.

\section{Olive Oil in the Ancient Middle East and Hebrew Bible}

Ancient Canaan or Palestine (called also "the Fertile Crescent") in the territory of modern Israel, Palestine, Jordan, Lebanon and parts of Syria was known as a source of olive oil, which was exported to Egypt where no oil was produced ${ }^{14,16,17)}$. The export of oil from Ancient Israel to Phoenicia and Egypt is mentioned in the HB: "So Hiram gave Solomon cedar trees and fir trees according to all his desire. And Solomon gave Hiram twenty thousand measures of wheat for food to his household, and twenty measures of pure oil. Thus gave Solomon to Hiram year by year." (1 Kings 5:25) Hiram was a Phoenician king of Tyre (c. 970-936 BC), while Solomon was the king of Judea (c. 970-930 BC), who used the trees, which he bought from king Hiram, to build the Temple in Jerusalem.

"Ephraim... do make a covenant with the Assyrians, and oil is carried into Egypt" (Hosea 12:2). The Prophet Hosea's evidence is dated with the $8^{\text {th }}$ century $\mathrm{BC}$ and the tribe of Ephraim, residing to the north of Jerusalem, is meant.

Oil (שמן shemen in Hebrew) was used for various purposes, including food, aromatization, it had also a sacral function (for example, Jacob pours oil for Beth-El altar, Genesis 28:18, 31:14) and was used for sanctification of an altar or anointing a new king. Smearing oil at a surface is called by the verb משח mashakh, while sliding and friction are called מלק khalaq. The later root also has the meaning of "to make smooth/slippery" and "to flatter". For example

אך בחלקות תשית למו הפלרתם למשואות "'sury

:"Surely thou did set them in slippery places; thou cast them down into destruction" Psalms (Ps) 73:18,

יהי-דרכם חשך וחלקלקת ומלאך ה' רדפים

"Let their way be dark and slippery" (Ps 35:6), לשונם יחליקון 
"They flatter with their tongue" (Ps 5:10).

It is noted that these three words, שמח shemen mashakh, and חלק khalaq, belong to the same semantic המשחה שמן shemen ham-mishkha ("the smearing/anointing oil") and Kלק משמן khalaq mish-shemen ("smoother than oil"):

חלקו מחמאות פיו.... רכו דבריו משמן

"His mouth was smoother than butter... his words were softer than oil" (Ps 55:22),

כי נפ̄ת תטפנה שפפתי זרה וחלק משמן חכה

"Because honey flows from the lips of a woman, her mouth is smoother than oil" (Proverbs 5:3),

השתים במזרקי יין וראשית שמנים ימשחו

"That drink wine in bowls, and anoint themselves with the chief oils" (Amos 6:6),

ולקחת את-שמן המשחה ויצקת על-ראשו ומשחת אתו

"Then take the smearing oil, and pour it upon his head, and anoint him" (Exodus 29:7). Thus in the Biblical Hebrew oil was associated with smearing or anointing, which led to softening of a surface making it smoother or slippery.

\section{Anointing the shields in Hebrew Bible}

There are direct references in the HB of using oil for tribological purposes ${ }^{18)}$. In two places smearing of a leather shield with oil is mentioned:

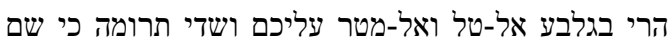

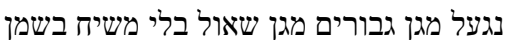

"Ye mountains of Gilboa, let there be no dew, neither let there be rain, upon you, nor fields of offerings; for there the shield of the mighty is vilely cast away, the shield of Saul had not been anointed with oil", 2 Samuel 1:21.

קומו השרים משחו מגן

"Arise, ye princes, and anoint the shield", Isaiah 21:5.

Saul was the first king of Judea in the $11^{\text {th }}$ century BC. The two books of Samuel are "pre-exilic" meaning that they were completed in their final form before the $6^{\text {th }}$ century $\mathrm{BC}$, with many parts being much older.

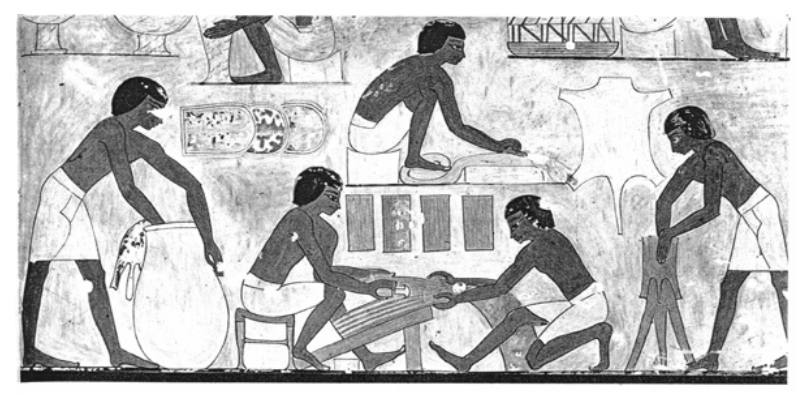

Fig. 3 A tomb painting from Theba (Egypt) shows manufacturing of leather-covered shields, with finished shields appearing at the upper left $\left(2^{\text {nd }}\right.$ millennium BC).
The purpose of rubbing the shields with oil was discussed by scholars. Unfortunately, our knowledge about the shields, which were used by the Israelites in the $11-8^{\text {th }}$ centuries BC, is limited. It is believed, that the shields were made of wood and leather and could have a metal disk attached ${ }^{19)}$ (Fig. 3). It is believed that the term shield (מגן magen in Hebrew) meant a small round shield or buckler, while a big shield covering the body was called צנה sinna ${ }^{20)}$. According to most commentators and scholars (e.g. Rashi), the shields were smeared with oil in order to make them smoother for enemy weapon to slip. The fundamental Brown-Driver-Briggs (BDB) dictionary describe smearing as necessity to "anoint the shield to make it slippery" ${ }^{21)}$. According to H. Graetz and S.R. Driver, the expression כלי משוח keli mashuakh ("anointed weapon") is related to this custom (cf. Ezekiel 9:1) ${ }^{21)}$.

A completely different interpretation of 2 Samuel 1:21 was proposed by D. N. Friedman, who studied the biblical poetic lamentation over Saul and Jonathan (Fig. 4). He believes that the word מגן should be read magan meaning "benefactor, suzerain, or chieftain" in analogy with the Phoenicean-Punic magon, which is rendered in Latin as "imperator". Furthermore, he translates the בלי ("without") as an affirmation rather than negation, which leads him to the translation "Saul the chieftain, who was duly anointed with oil" ${ }^{22)}$. However, Friedman's interpretation involves too many assumptions and does not explain the "anointed weapon" expression. While the word "shield" could be used metonymically as a figurative description of a ruler-"protector", who defends his servants, there is no ground for denying the literal meaning of anointing the shields with oil, and most scholars agree that the purpose was "to make them slippery", that is, to lubricate. It is noted, that using oil upon leather could serve also for other purposes than making it slippery, for example, to preserve it in the dry climates.

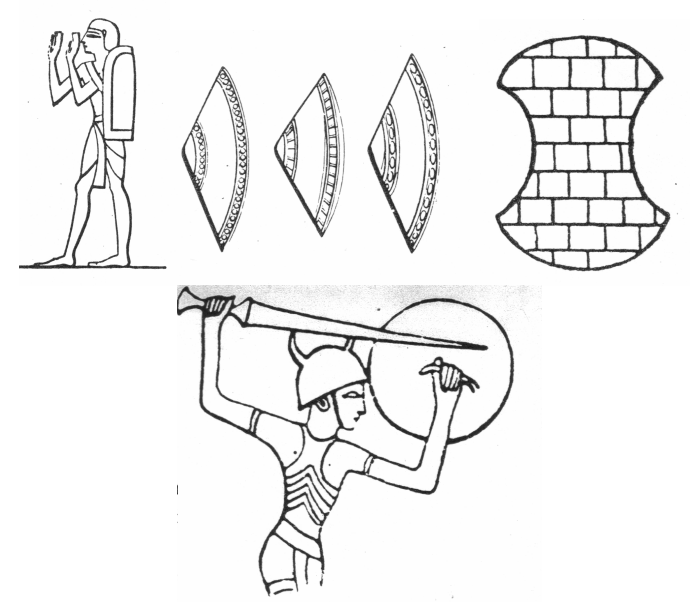

Fig. 4 Shields in the Middle East of the $2^{\text {nd }}$ millennium BC: Egyptian warrior with a shield (top left), assyrian shields (top center), Hittite "8-shaped" shield (top right), A round philistine shield in Palestine (bottom) 
The olive oil was used in various Mediterranean countries in the first millennium $\mathrm{BC}$ and, not surprisingly, it appears in the list composed by Pliny the Elder. In HB the word "oil" is mentioned 193 times, of these many times in conjunction with the verbs "to smear" and "to slip", indicating that it was utilized for tribological purposes.

\section{Sacral role of oil in the Middle Eastern cultures}

There is an argument between the paleobotanists on whether the olive (Olea europaea) appeared independently in the Aegean region and in the Fertile Crescent, however, there is no argument that the olive oil was an important product of the later region. In the $\mathrm{HB}$, the olive appears 18 times in the triad "corn, wine, oil" and among the Seven Kinds (Deuteronomy 8:8), which symbolized the agricultural products of the Mediterranean region. There is elaborated terminology for oil production in Biblical Hebrew. Olive oil played an important role in local cultures and sometimes had a sacral function due to its special properties. Special functions were attributed to the oil in the mystical teachings of the Cabbala, Sufism, and Alchemy.

The Talmud $\left(1^{\text {st }}-5^{\text {th }}\right.$ centuries CE) and medieval Jewish mystic teaching of the Cabbala, parts of which have very ancient roots, oil and wine, the two products common in the Mediterranean region, were both considered sacred liquids, with oil having the same smoothening effect upon the objects of the material world, as wine upon the intellect and spiritual world (Zohar, Lekh, 265, Shemini, 61).

Olive oil played a significant role also in the Muslim mystic teaching of Sufism, since the Koran compares the God with "An Olive, neither of the East nor of the West, whose oil is well-nigh luminous, though fire scarce touched it; Light upon Light!" (An-Nur 24:35).

The medieval Muslim, Christian, and Jewish traditions of alchemy, which were related to the Cabbala and studied intensively all data, hints and allusions about chemistry in the Bible and other Hebrew texts, and later became a foundation for the science of chemistry, also deal with oil ${ }^{23)}$. Thus, according to the Arab alchemist Jabir ibn Khayyan as well as other alchemists, oil was the last liquid to rise in distillation, its evaporation leaves behind only powdery residue. Therefore, oil, or unctuous moisture, symbolized permanent liquidity and was among the "four components of a substance" (according to Aristotle), responsible for cohesion ${ }^{24)}$.

We conclude that oil was widespread in the Middle Eastern cultures and had a great importance. Due to its special properties, including the tribological properties such as the ability to smoothen a surface and make it slippery, sacral and mystical values were also attributed to oil.

\section{Conclusions}

Summarizing, we see, that although there is evidence about the use of lubricants already in the second and third millennia BC in Egypt, this evidence, which entered many tribology textbooks ${ }^{25,26)}$, is hypothetical rather than well established. The famous Egyptian funeral paintings of men pouring liquid in front of statues in Saqqara and El Bersheh could show "the first lubrication engineers", however, they can have also other equally possible interpretations. The HB depicting the shield of King Saul (c. 1010 BC) is the first historically recorded use of oil for lubrication. Oil played an important role in the cultures of eastern Mediterranean region, and due to its notorious softening and smoothening tribological properties it received a sacral status in different local religious and mystic traditions. This may provides with a missing link between the early civilizations and Roman and European technology.

\section{Acknowledgements}

The author would like to thank Dr. Jorn Larssen-Bosse from the National Science Foundation tribology program (Washington, D.C.) and Prof. Jacob Klein from Weizmann Institute (Israel) and Oxford University for their important suggestions.

\section{References}

[1] Dowson, D., History of Tribology, $2^{\text {nd }}$ ed., PEP, London, 1998, 32-57.

[2] Parish, W. F., "Three Thousand Years of Progress in Developing Machinery and Lubricants for the Hand Crafts," Mill and Factory, 16, 1935, 27-30, 86-87.

[3] Kragelskii, I. V. and Shchedrov, V. S., Razvitie Nauki o Trenii (Development of the Science of Friction), Academy of Science, Moscow, 1956.

[4] Davison, C., "Wear Prevention in Early History," Wear, 1, 1957, 155-159; "Wear Prevention between 25 BC and 1700 AD," Wear, 2, 1958, 59-63.

[5] Bartz, W. J., Zur Geschichte der Tribologie, Expert, Ehningen, 1988.

[6] Buyanovskij, I. A., Fuks, I. G. and Bagdasarov, L. N., "Ocherki po Istorii Tribologii," (Essays on the History of Tribology), Neft I Gaz, Moscow, 1998.

[7] Georges, J. M, Zahouani, H. and Vargiolu, R., "Divers Visages de la Tribologie," Dossiers d'Archéologie, 290, 2004, 4-7.

[8] Astruc, L., Vargiolu, R. and Zahouani, H., "Wear Assessments of Prehistoric Instruments," Wear, 255, 2004, 341-347.

[9] Carnes, K., "The Ten Greatest Events in the Tribology History," Tribology and Lubrication Technology, 61, 2005, 38-47.

[10] Saliba, G., Rethinking the Roots of Modern Science: Arabic Scientific Manuscripts in 
European Libraries, Georgetown University, Washington, 1999.

[11] Huff, E., The Rise of Early Modern Science: Islam, China and the West, Cambridge University Press, Cambridge, 1993.

[12] Clarke, S. and Engelbach, R., Ancient Egyptian Masonry - the Building Craft, Oxford University Press, Oxford, 1930.

[13] Layard, A. H., Discoveries in the Ruins of Nineveh and Babylon, J. Murray, London, 1853.

[14] Ahitov, S., Observations on Olive Oil in Ancient Egypt, Olive Oil in Antiquity, eds. D. Eitham and M. Heltzer, Padova, 1996, 41-44.

[15] Newberry, P. E., El-Bersheh-Part 1. The Tomb of Tehutu-Hetep, Archaeological Survey of Egypt, ed. Griffith, F. L., Egypt Exploration Fund, London, 1893.

[16] Ahlström, G. W. Zayith (olive), Theological Dictionary of the Old Testament, eds. Botterweck, G. J. and Ringgren, H., W.B.Eerdmans Pub. Co., Grand Rapids, MI, 7, 1980, 58-61.

[17] Frankel, R., "Olives," The Oxford Encyclopaedia of Archaeology in the Near East, Ed. M. Meyers, New York, Oxford University Press, 4, 1997, 179-184.

[18] Nosonovsky, M., "Material about the History of Tribology in the Hebrew Bible," Proceedings of the
Third Asia International Conference on Tribology, 2006, 725-726.

[19] Yadin, Y., "The Art of Warfare in Biblical Lands in the Light of Archaeological Discovery," NY, 1, 1963, 13-14.

[20] Friedman, D. N. and O'Connor, M. P., "Magen (shield)," Theological Dictionary of the Old Testament, eds. Botterweck, G. J. and Ringgren, H., W.B. Eerdmans, Pub. Co., Grand Rapids, MI, 8, 1980, 74-86.

[21] Brown, F., Driver, S. R. and Briggs, C. A., "The Brown-Driver-Briggs Hebrew and English Lexicon," Hendrickson, Peabody, MA, 2000, 171, 603.

[22] Friedman, D. N., The Refrain in David's Lament over Saul and Jonathan, Pottery, Poetry, and Prophesy: Studies in Early Hebrew Poetry, Eisenbranus, Winona Lake, 1980, 263-274.

[23] Patai, R., The Jewish Alchemists, Princeton University, Princeton, 1994.

[24] Freudental, G., (Al)chemical Foundation for Cosmological Ideas: Ibn Sina and the Geology of the Eternal World, Science in the Medieval Hebrew and Arabic Traditions, Variorum, Aldershot, 2005.

[25] Williams, J. A., Engineering Tribology, Oxford University Press, Oxford, 1994, 28.

[26] Bhushan, B., Introduction to Tribology, Wiley, New York, 2002, 2. 